\title{
A sad farewell and a new start
}

\author{
A. van Belkum
}

Published online: 24 November 2007

(C) The Author(s) 2007

The office of the European Journal of Clinical Microbiology and Infectious Diseases (EJCMID) has been a hectic place over the past year. With the unfortunate passing away of founding editor Professor Ilja Braveny early 2007, a passionate and dedicated Editor in Chief was lost. Professor Braveny had enthusiastically led the journal for more than two decades and he was the personification of EJCMID. In Professor Braveny we lost a prominent and influential representative of EJCMID. Professor Dana Milatovic filled Prof. Braveny's position for a number of months. This guaranteed the journal's continuity and we gratefully acknowledge Professor Milatovic's dedication and hard work.

Springer, the publisher of EJCMID, has invited me to take over the position of Editor in Chief from June 2007. Since then, I have had ample opportunity to get to know the journal from the inside. The journal is healthy: over the summer period alone, more than 200 papers were submitted and dealt with. Evaluation and judgment of such a number of papers is a tough job which could not have been performed without the administrative support of Nele Jung, who is the heart of the office, and has been associated with the EJCMID for a long time.

A significant fraction of the submissions involve brief case reports and concise clinical observations. Although from a historical perspective such manuscripts have always formed an integral part of the EJCMID's content, the current editorial team will be changing policies over the coming year and this will surely affect the number of short

A. van Belkum $(\triangle)$

Department of Medical Microbiology and Infectious Diseases,

Erasmus MC,

s'-Gravendijkwal 230,

3015 CE Rotterdam, The Netherlands

e-mail: a.vanbelkum@erasmusmc.nl communications with a clinical-practice focus that will be included in future issues. It will be our long-term goal to further improve the impact factor of EJCMID and we all feel that in order to achieve this, changes in editorial policy including this one are really necessary. There will be a gradual change in the scope of the journal. Whereas the current content of the journal represents, in a melting pot manner, all aspects of clinical microbiology and infectious diseases, we intend to re-orient and focus towards a smaller number of clinical-scientific subjects. We may even consider a new name. "Infectious Microbiology" would neatly encapsulate the focus.

The journal will become a vehicle for post-genomic research in the field of bacterial infectious diseases. It will specifically focus on the publication of high quality manuscripts in any of the following separate or, preferably, combined fields of interest.

1. Epidemiology of bacterial virulence genes.

2. The genetics and phenotypes of host susceptibility to bacterial infection.

3. Animal models of bacterial infections.

4. Imaging of bacterial infections

This will require a major change in the current policy of the journal and we hope that it will not only lead to even higher quality submissions and, therefore, publications, but also to an additional group of readers. We will start to implement these changes over the year to come by introducing specific journal sections dedicated to the topics listed above.

To introduce these changes is an editorial challenge, but it will be supported by continuity in the impact factor. Changing a journal's scope and header will not necessarily affect the impact factor and in this way the new start of EJCMID will not lead to a lesser impact and, thereby, a lower visibility. 
EJCMID will - under a new name - provide a forum for the dissemination of scientific data that integrate findings of the various fields relating to bacterial infectious diseases and medical microbiology. The ultimate goal is to describe the etiology and development of bacterial infections in human or animal hosts from a holistic and detailed perspective. Epidemiological application of the assessment of genetic variation of bacterial isolates can also be used to identify virulence genes of interest. The interaction of virulence gene products with human or animal hosts could be visualized from the genetic perspective: which are the host genes that define the susceptibility or resistance to infections. Infectious processes and their dynamics could also be studied using imaging technologies. Papers to be published in EJCMID in the future should optimally be positioned at the cutting edge of the major topics listed above and should appreciate translational application of findings.

We will continue to publish full papers describing innovative research. Next to original work, Full Reviews and MiniReviews will be published. The journal will use Editorial Manager as the electronic submission system. Supported by a team of internationally renowned section editors including a dedicated Reviews Editor, I will serve as Editor in Chief. Although we are actively searching for researchers knowledgeable in one of the four fields identified above those interested in one of the editorial positions are invited to express their interest.

I hope that we will be facing a healthy future for EJCMID and that we will be able to guarantee continuity for the journal once established by the late Professor Ilja Braveny. I am looking forward to receiving the support of section editors, our readership and, last but not least, the high quality reviewers on whom EJCMID has always been able to rely.

Open Access This article is distributed under the terms of the Creative Commons Attribution Noncommercial License which permits any noncommercial use, distribution, and reproduction in any medium, provided the original author(s) and source are credited. 